\title{
Amino Acid Sequence of Bumblebee MCD Peptide: A New Mast Cell Degranulating Peptide From the Venom of the Bumblebee Megabombus pennsylvanicus
}

\author{
ANTONIO ARGIOLAS,* PATRICIA HERRING AND JOHN J. PISANO \\ *Institute of Pharmacology. University of Cagliari. Via Porcell 4,09100 Cagliari, Italy. \\ and Section of Physiological Chemistry, Laboratory of Chemistry
}

National Heart, Lung and Blood Institute. National Institutes of Health. Bethesda. MD 20205

\begin{abstract}
ARGIOLAS. A., P. HERRING AND J. J. PISANO. Amino acid seculence of bumblebee MCD peptide: A ne'w mast cell degranulating peptide from the venom of the bumblebee Megabombus pennsylvanicus. PEPTIDES 6: Suppl. 3, 431-436. 1985. - A new 28 amino acid peptide. we recently isolated from the venom of the bumblebee Megabombus peminsy/hanicus. has been characterized. The peptide. Met-Cys-Ile-Cys-Lys-Asn-Gly-Lys-Pro-Leu-Pro-Gly-Phe-Ile-Gly-Lys-lle-CysArg-Lys-Ile-Cys-Met-Met-Gln-Gln-Thr-His $\left(\mathrm{NH}_{2}\right)$, has been named bumblebee mast cell degranulating (MCD) peptide due to its ability to degranulate rat peritoneal mast cells and its resemblance to the bee venom MCD peptide. Bumblebee MCD peptide, unlike bombolitins, the other mast cell degranulating heptadecapeptides of bumblebee venom, is not lytic and releases histamine at a dose as low as $0.05 \mu \mathrm{g} / \mathrm{ml}\left(1.6 \times 10^{-\mathrm{k}} \mathrm{M}\right)$.
\end{abstract}

Amino acid sequence Bumblebee MCD peptide Bumblebee venom

RECENTLY we reported the isolation and characterization of hombolitins, a new class of lytic mast cell degranulating heptadecapeptides from the venom of the bumblebee Masubombus pennsyliranicus [3]. In addition to bombolitins, we found that bumblebee venom contains other active peptides. Although less abundant than bombolitins, one of these peptides stimulated histamine release from rat peritoneal mast cells at a dose as low as $20 \mathrm{nM}$. We report here the complete sequence of this specific bumblebee mast cell degranulating (MCD) peptide.

\section{METHOD}

The following were purchased: venom sacs and pure dry venom of Megabombus pennsy/ranicus (Vespa Laboratories. Spring Mills, PA); trypsin-TPCK treated, thermolysin. subtilisin and carboxypeptidase $A$ (Boehringer Mannheim Biochemicals). Reagents and chemicals for sequencing were sequanal grade from Pierce Laboratories. All other reagents were of the highest available purity.

\section{Peptide Isolation}

Bumblebee MCD peptide was isolated from pure venom or venom sac extracts as previously described [3]. Briefly, aliquots equivalent to $0.16 \mathrm{mg}$ of pure venom or to $0.5 \mathrm{sac}$ were fractionated at room temperature on a $\mathrm{C}_{1 \times} \mu$ Bondapak column $(0.39 \times 30 \mathrm{~cm}$, Waters Assoc. $)$ mounted in a Varian 5000 high performance liquid chromatograph equipped with a variable wavelength $U V$ detector. The linear gradient $(20$ to $100 \% \mathrm{~B}$ in $60 \mathrm{~min}$, flow $1 \mathrm{ml} / \mathrm{min}$ ) was made with $\mathrm{A}=0.05 \%$ trifluoroacetic acid and $0.025 \%$ triethylamine in water, and $B=$ the same reagents in 80:20 acetonitrile:water. Bumblebee MCD peptide eluted as a very sharp peak at $19 \mathrm{~min}$ (Fig. 1).

\section{Bioassay}

Hemolysis of guinea pig erythrocytes and histamine release from purified rat peritoneal mast cells were performed as previously described [2].

\section{Amino Acid and Secuence Analysis}

Samples were hydrolyzed in evacuated sealed tubes with $6 \mathrm{~N} \mathrm{HCl}$ for $24 \mathrm{hr}$ at $110^{\circ} \mathrm{C}$ and amino acids were determined with a Beckman 6300 amino acid analyzer essentially by the method of Spackman, Moore and Stein [11]. Amino acid sequences were determined manually by dansyl [5] and dimethylamino-azobenzene-isothiocyanate (DABITC)phenylisothiocyanate (PITC) methods [4]. Dansyl- and dimethylamino-azobenzene-thiohydantoin (DABTH) amino acids were identified by thin layer chromatography using $5 \times 5 \mathrm{~cm}$ polyamide plates (Schleicher \& Schuell). Automated Edman degradation was performed with a Caltech gas phase 
TABLE 1

AMINO ACID ANALYSIS OF BUMBLEBEE MCD PEPTIDE AND ITS FRAGMENTS

\begin{tabular}{|c|c|c|c|c|c|c|c|}
\hline $\begin{array}{l}\text { Amino } \\
\text { acid }\end{array}$ & $\begin{array}{c}\mathrm{BB} \underset{\mathrm{P}}{\mathrm{MCD}} \\
\mathrm{P}\end{array}$ & $\begin{array}{c}\text { BB MCD } \\
\mathrm{Tl}\end{array}$ & $\begin{array}{c}\text { BB MCD } \\
\mathrm{T}_{2}\end{array}$ & $\begin{array}{c}\text { BB MCD } \\
\text { Tla }\end{array}$ & $\begin{array}{c}\text { BB MCD } \\
\text { TIb }\end{array}$ & $\begin{array}{c}\text { BB MCD } \\
\text { T Ic }\end{array}$ & $\begin{array}{c}\text { BB MCD } \\
\text { TISS }\end{array}$ \\
\hline CmCys & & & & $0.8(1)$ & $1.7(2)$ & $0.9(1)$ & \\
\hline Asx & $1.2(1)$ & & $1.1(1)$ & & & & \\
\hline Thr & $0.8(1)$ & $0.8(1)$ & & & & $0.8(1)$ & $0.8(1)$ \\
\hline Glx & $2.1(2)$ & $2.2(2)$ & & & & $2.0(2)$ & $2.1(2)$ \\
\hline Pro & $1.9(2)$ & & $2.0(2)$ & & & & \\
\hline Gly & $3.3(3)$ & & $3.2(3)$ & & & & \\
\hline $1 / 2$ Cys & $3.8(4)$ & 4. $1(4)$ & & & & & $1.8(2)$ \\
\hline Met & $2.5(3)$ & $2.8(3)$ & & & $0.9(1)$ & $1.8(2)$ & $1.7(2)$ \\
\hline Ile & $3.8(4)$ & $3.0(3)$ & $1.0(1)$ & $1.0(1)$ & $1.0(1)$ & $1.0(1)$ & $0.8(1)$ \\
\hline Leu & $1.0(1)$ & & $1.2(1)$ & & & & \\
\hline Phe & $0.8(1)$ & & $0.9(1)$ & & & & \\
\hline $\mathrm{His}$ & $1.2(1)$ & $1.0(1)$ & & & & $1.0(1)$ & $1.0(1)$ \\
\hline Lys & $3.9(4)$ & $1.9(2)$ & $1.8(2)$ & & $0.8(1)$ & $0.9(1)$ & $0.8(1)$ \\
\hline Arg & $0.9(1)$ & $0.9(1)$ & & $0.9(1)$ & & & \\
\hline Residues & 28 & 17 & 11 & 3 & 5 & 9 & 10 \\
\hline
\end{tabular}

The peptide did not show any absorbance peaks near $280 \mathrm{~nm}$ indicating the absence of Trp.

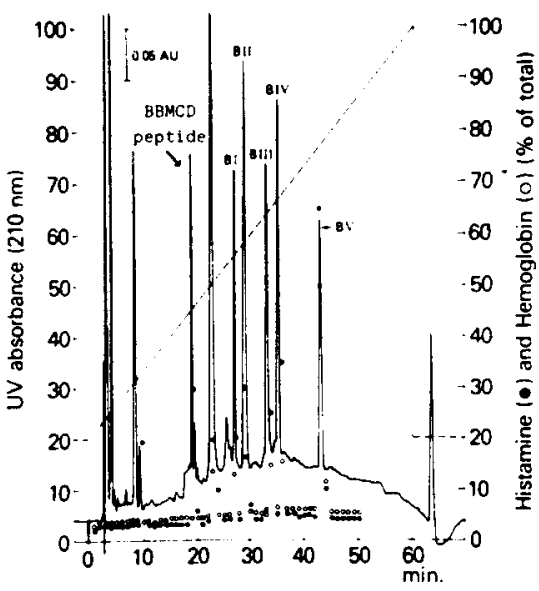

FIG. 1. High performance liquid chromatography fractionation of peptides in Megabombus pennsylvanicus venom. Sample: $0.16 \mathrm{mg}$ dry weight venom in $50 \mu \mathrm{l}$ of $0.05 \%$ trifluoroacetic acid. Column: $C_{1 .} \mu$ BONDAPAK $0.39 \times 30 \mathrm{~cm}$; temp. ambient. Solvent A: $0.05 \%$ trifluoroacetic acid and $0.025 \%$ triethyl amine in water: Solvent B: the same reagents in 80:20 acetonitrile:water. Linear gradient: from 20 to $100 \% \mathrm{~B}$ in $60 \mathrm{~min}$. Flow: $1 \mathrm{ml} / \mathrm{min}$. One $\mathrm{ml}$ fractions were collected, concentrated in a Speed Vac (Savant). dissolved in $200 \mu \mathrm{l}$ water and assayed for histamine release and erythrocytes hemolysis [2].

sequenator. Phenyl-thiohydantoin (PTH) amino acids were identified at $269 \mathrm{~nm}$ on a Hewlett Packard high performance liquid chromatograph equipped with a $0.4 \times 25 \mathrm{~cm}$ Zorbax ODS column (Du Pont) as previously described [10].

\section{RESULTS}

From amino acid analysis, we calculated that from $9 \mathrm{mg}$

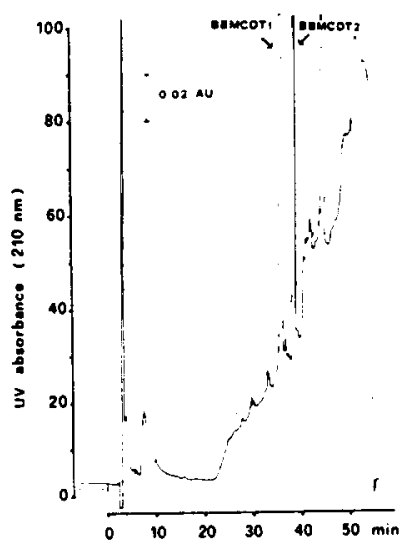

FIG. 2. High performance liquid chromatography fractionation of tryptic peptides of the bumblebee MCD peptide. Two nmol of intact peptide were incubated at $37^{\circ}$ for $1 \mathrm{hr}$ with $0.5 \mu \mathrm{g}$ trypsin-TPCK in $50 \mu \mathrm{l}$ of $50 \mathrm{mM}$ Tris- $\mathrm{HCl}$ pH 8.0. Sample: the entire reaction mixture. Linear gradient: 2 to $20 \% \mathrm{~B}$ in 30 min and to $80 \% \mathrm{~B}$ in the next $20 \mathrm{~min}$. The other conditions were as in Fig. I. except that triethylamine was ommitted from Solvent A and B.

of dry venom $8 \mathrm{nmol}$ of bumblebee MCD peptide were isolated. and from one sac $0.2-0.3 \mathrm{nmol}$.

\section{Amine Acid and Sequence Analysis}

Amino acid analysis revealed that bumblebee MCD peptide is a highly basic 28 amino acid peptide (Table 1). It contains 4 Lys. 1 Arg and 1 His together with $41 / 2$ Cys and no 
TABLE 3

AUTOMATED EDMAN DEGRADATION OF BUMBLEBEE MCD PEPTIDE

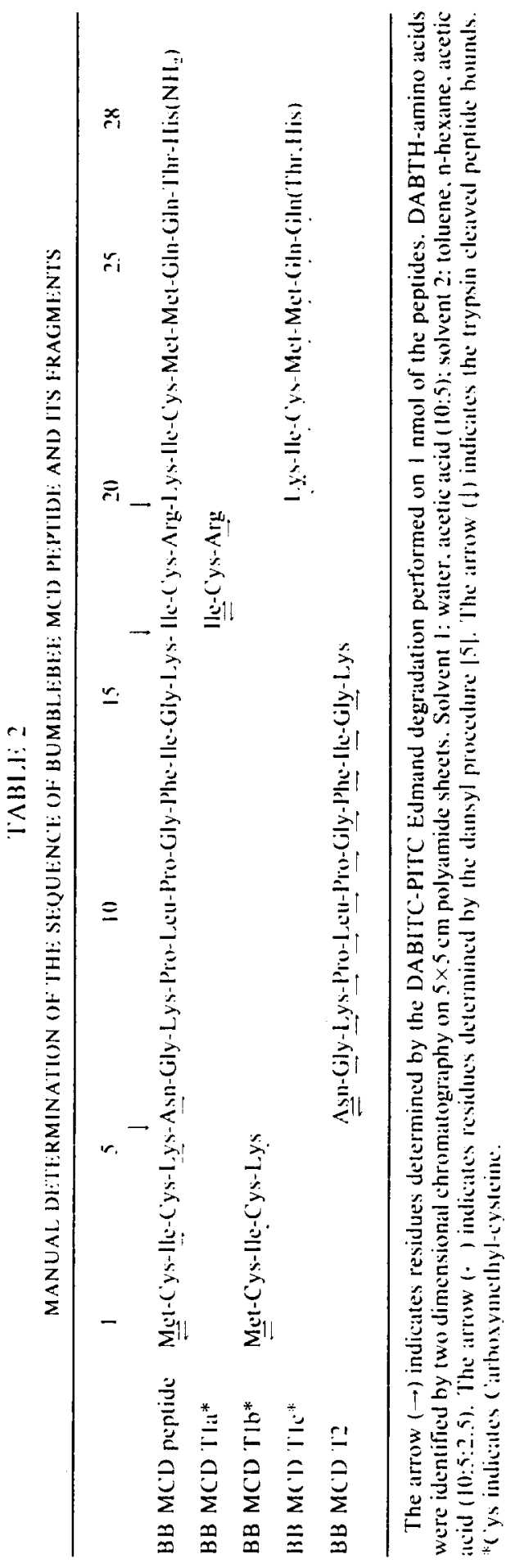

\begin{tabular}{|c|c|c|}
\hline Step & $\begin{array}{l}\text { Amino } \\
\text { acid }\end{array}$ & $\begin{array}{l}\text { Yield } \\
(\%)\end{array}$ \\
\hline 1 & Met & 78 \\
\hline 2 & - & - \\
\hline 3 & Ile & 80 \\
\hline 4 & - & - \\
\hline 5 & Lys & 63 \\
\hline 6 & Asn & 81 \\
\hline 7 & Gly & 71 \\
\hline 8 & Lys & 54 \\
\hline 9 & Pro & 72 \\
\hline 10 & Leu & 51 \\
\hline 11 & Pro & 65 \\
\hline 12 & Gly & 46 \\
\hline 13 & Phe & 53 \\
\hline 14 & Ile & 48 \\
\hline 15 & Gly & 36 \\
\hline 16 & Lys & 25 \\
\hline 17 & lle & 10 \\
\hline 18 & - & - \\
\hline 19 & Arg & 1 \\
\hline 20 & Lys & 8 \\
\hline 21 & lle & 5 \\
\hline 22 & - & - \\
\hline 23 & Met & 4 \\
\hline 24 & Met & 3 \\
\hline 25 & Gln & 2 \\
\hline 26 & Gin & 2 \\
\hline 27 & Thr & 1 \\
\hline 28 & $\mathrm{His}$ & $i$ \\
\hline
\end{tabular}

The intact peptide $(1.3 \mathrm{nmol})$ was sequenced. PHT-amino acids were identified by high performance liquid chromatography [10]. No PTH amino acid was identified at cycles 2, 4, 18 and 22 (Cys).

free sulfidryl group. The amino terminal amino acid Met was determined by both the dansyl and DABITC methods. Digestion with trypsin gave only two peptides. BB MCD TI and BB MCD T2 (Fig. 2 and Table 1) with a 75\% yield. although 6 peptides were theoretically expected. $\mathrm{N}$-terminal amino acid analysis revealed Met. Ile and Lys at the $\mathrm{N}$-terminal of $\mathrm{BB}$ MCD Tl and Asn at the $\mathrm{N}$-terminal of $\mathrm{BB}$ MCD T2. Reduction with dithiothreitol and carboxymethylation with iodoacetic acid of BB MCD TI produced 3 peptides which were separated by high pressure liquid chromatography, BB MCD Tla, BB MCD TIb and BB MCD TIC. with Ile. Met and Lys at their $\mathrm{N}$-terminal, respectively (Fig. 3 and Table 1). BB .ICD T la was covered by a huge peak of UV absorbing material (Fig. 3). In order to localize BB MCD $\mathrm{Tla}$, one $\mathrm{ml}$ fractions were collected during the elution of the UV absorbing material, concentrated with a Sped-Vac, subjected to acid hydrolysis and analyzed for the presence of amino acids. As the UV absorbing material did not interfere with amino acid analysis. BB MCD Tla was found $7 \mathrm{~min}$ after the injection. Mlanual sequencing of $B B$ MCD Tla. $B B$ MCD T/b. BB MCD T/c and BB MCD T2 was straightforward. except for the last 2 amino acids of BB MCD T Ic (Thr 


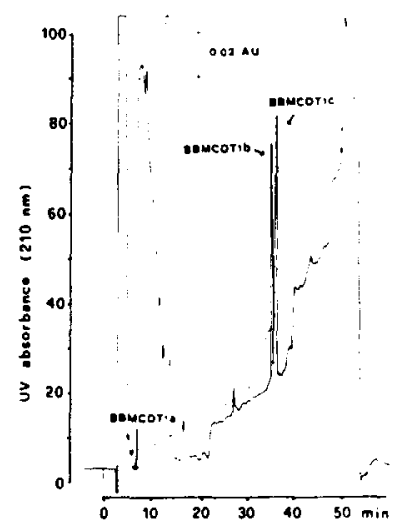

FIG. 3. High performance liquid chromatography fractionation of BB MCD T1 after reduction and carboxymethylation. BB MCD T1 (Fig. 1) $(1.4 \mathrm{nmol})$ was incubated $1 \mathrm{hr}$ at $37^{\circ}$ with $0.12 \mathrm{mM}$ dithiothreitol in $50 \mu \mathrm{l}$ of $0.2 \mathrm{M} \mathrm{N}$-methyl-morpholine- $\mathrm{HCl} \mathrm{pH} 8.5$. Iodoacetic acid was added to the reaction mixture in $20 \mu$ lof the above buffer to a final concentration of $0.24 \mathrm{mM}$. The incubation was continued for $1 \mathrm{hr}$ at $37^{\circ}$ and stopped by injecting the entire reaction mixture in the column. The peptides were fractionated by using the same conditions reported in Fig. 2. In order to localize BB $\mathrm{MCD} \mathrm{Tla}$ one $\mathrm{ml}$ fractions were collected and concentrated with a Speed Vac. After acid hydrolysis at $110^{\circ}$ in sealed evacuated tubes. the amino acid composition revealed the presence of the peptide. No interference was found due to the huge peak of UV absorbing material.

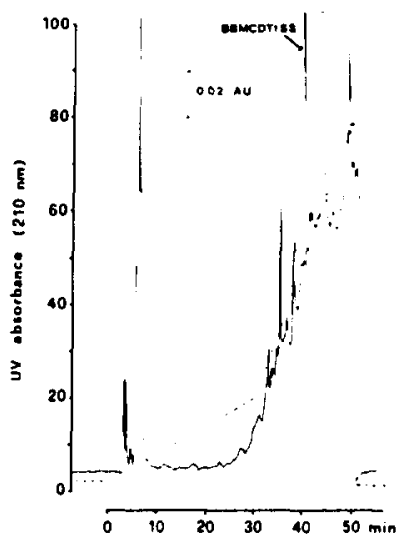

FIG. 5. High performance liquid chromatography of BB MCD TI after 2 Edman degradation cycles. One nmol of BB MCD T1 was subjected to 2 manual Edman degradation cycles. The shortened peptide was redissolved in $50 \mu \mathrm{l}$ Solvent $\mathrm{A}$. injected and fractionated as described in Fig. 2.

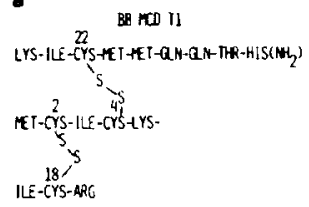
2 EIman cecandaitón.

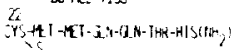

${ }_{4}$ $-\frac{1}{3}$

45

b

LYS-ILE-CYSS-FET-NET-QN-GN-MR-HISSWH

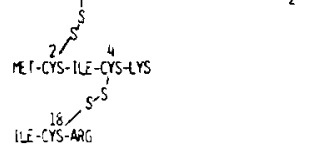

2 EIMAS TEGACATIOA

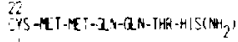
$\dot{\gamma}$

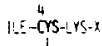
Anis

LYS-X $=E-$-THTO-CARBAM - LYS

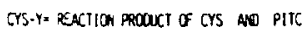

FIG. 4. Scheme of the reaction for the assignment of the disulfide bridges in BB MCD T1. (a) Disulfide bridges between Cys ${ }^{2}-C y s^{\prime n}$ and $\mathrm{Cys}^{4}-\mathrm{Cys}^{22}$ : (b) Disulfide bridges between $\mathrm{C}_{\mathrm{s}^{2}}-\mathrm{Cys}{ }^{22}$ and $\mathrm{Cys}^{4}-\mathrm{Cys}^{11}$. See the Results section for details.

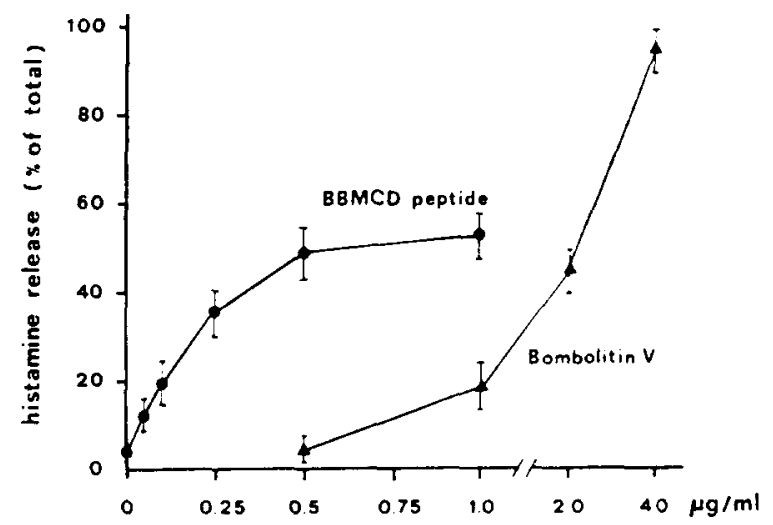

FIG. 6. Histamine release from rat peritoneal mast cells induced by bumblebee MCD peptide and bombolitin $\mathrm{V}$. The peptides were incubated with $10^{\circ} \mathrm{cell} / \mathrm{sample}$ at $37^{\circ} \mathrm{C}$ for $5 \mathrm{~min}$ without shaking in 200 $\mu$ of medium [12]. The reaction was stopped by cooling the samples with ice cold water and centrifugating at $1500 \times \mathrm{g}$ for $10 \mathrm{~min}$. Histamine was determined in the supernatant spectrophotofluorometrically [1]. Total histamine was determined by sonication of the cells. 
and His) which could not be assigned by the manual methods. The knowledge of the N-terminal amino acid. the partial sequence of the intact peptide and trypsin cleavages permitted the alignment of the tryptic fragments (Table 2). Automatic Edman degradation of $1.3 \mathrm{nmol}$ of the intact peptide confirmed the sequence obtained manually and allowed the assignment of $\mathrm{Thr}^{2 \pi}-\mathrm{His}^{2 \mathrm{x}}$, although no amino acid was identified at cycles 2, 4, 18 and 22. occupied by Cys (Table 3). Incubation of the intact peptide with carboxypeptidase $A$ (peptide:enzyme $1: 20,2 \mathrm{hr}$ at $37^{\circ} \mathrm{C}$ ) did not release any His or other amino acids, indicating that the C-terminal is blocked, probably amidated. However, attempts to release HisNH. with thermolysisn and subtilisin [13] were unsuccessful, although many amino acids were released.

\section{Assignment of Disulfide Bridge's}

Digestion by trypsin of the intact peptide ruled out the presence of disulfide bridges between $\mathrm{C} y s^{2}-\mathrm{Cys} s^{4}$ and Cys ${ }^{1 *}-C y s^{\prime 2}$ leaving only 2 possibilities: Cys $s^{2}-C y s^{1 *}$ and $\mathrm{Cys}^{4}-\mathrm{Cys}^{22}$ or Cys $\mathrm{S}^{2}-\mathrm{Cys}^{22}$ and $\mathrm{Cys}^{4}-\mathrm{Cys}^{1 \times}$. Since both bridges were present in BB MCD T1, 2 manual Edman degradation cycles were performed on this peptide. The scheme of the reaction is shown in Fig. 4. According to the first possibility, free Arg and only one peptide containing the intact disulfide bridge Cys ${ }^{4}-\mathrm{Cys}^{22}$ would be obtained, while free Arg and 2 peptides would be produced if the second possibility were correct. High pressure liquid chromatography of BB MCD TI after 2 manual Edman degradation cycles produced free Arg which eluted in the void volume and only one peptide with the expected amino acid composition and an intact disulfide bridge (BB MCD TISS. Fig. 5 and Table 1). indicating that the first possibility is the correct one. Determination of the $\mathrm{N}$-terminal amino acid of $\mathrm{BB}$ MCD TISS gave only lle. since the other expected amino acid. Cys. does not give any measurable product.

\section{Biological Actirity}

Bumblebee MCD peptide was tested in 2 bioassays: hemolysis of guinea pig erythrocytes and histamine release from rat peritoneal mast cells. The peptide was without effect up to a dose of $1 \mu \mathrm{g} / \mathrm{ml}$ on guinea pig ery throcytes (results not shown). On the other hand, the peptide induced a significant release of histamine at a dose as low as $0.05 \mu \mathrm{g} / \mathrm{ml}$ $\left(1.6 \times 10^{-4} \mathrm{M}\right)$ (Fig. 6). The maximal release $155 \%$ of total histamine) was obtained with $0.5 \mu \mathrm{g} / \mathrm{ml}$. On the contrary. bombolitin $\mathrm{V}$. the most potent bombolitin in the histamine release bioassay [3]. was $w$ ithout effect at $0.5 \mu \mathrm{g} \mathrm{ml}\left(3 \times 10^{-7}\right.$ $\mathrm{M})$ and induced only a $20 \%$ release at $1 \mu \mathrm{g} / \mathrm{ml}$. Due to its lytic effect. bombolitin $V$ released the total histamine content at doses higher than $4 \mu \mathrm{g} / \mathrm{ml}$ (Fig. 6).

\section{DISCUSSION}

Bumblebee MCD peptide represents less than $1 \%$ of the dry weight of the venom. On the contrary, bombolitins constitute $25-30 \%$ of the dry venom. The low amount of peptide caused some problems in the manual determination of the sequence of bumblebee MCD peptide. However, digestion with trypsin, reduction and carboxymethylation produced shorter peptides in amounts sufficient for the amino acid and sequence analysis. The presence of a Lys-Pro bound, resistent to trypsin, did not cause any problem, and only the last 2 amino acids could not be assigned by manual methods. On the other hand. the automatic Edman degradation of the in- 
tact peptide was straightforward, probably because of the high hydrophilic structure of the peptide, although the yield dropped to values lower than $10 \%$ in the last cycles. The isolation of a peptide that contains one of the 2 disulfide bridges intact allowed the assignment of both disulfide bridges. The only point that needs more investigation is the determination of the C-terminal blocking group. Although His $\mathrm{NH}_{2}$ was not released by thermolysin or subtilisin, the peptide is probably amidated, as are the majority of the peptides isolated from hymenopteran venoms.

Bumblebee MCD peptide is not related to bombolitins and its sequence represents a new structure that has to be added to the class of the specific, not lytic. mast cell degranulating peptides. Although a new sequence, bumblebee MCD peptide is somewhat related to the bee MCD peptide and apamine (Table 4). In fact, all 3 peptides contain 2 disulfide bridges, are rich in basic amino acids charged at physiological pH and lack the surfactant character of melittin, mastoparans and bombolitins. This is probably due to the disulfide bridges, which restrain the peptides in a particular configuration. The similarity is greater with bee MCD peptide than with apamine. The fragment 17-22 of bumblebee MCD peptide is identical to the fragment $14-19$ of the bee MCD peptide $[8,15]$ and the 2 peptides show the same potency in releasing histamine from rat peritoneal mast cells $[6,15]$. On the contrary, the similarity with apamine is restricted to the $\mathrm{C}$-terminal, since apamine does not release histamine $[6,15]$. Apamine is thought to be a neurotoxin [6] apparently for its ability to bind with high affinity to calcium-dependent potassium channels [9]. It is unknown whether this property is common also to bee and bumblebee MCD peptides. Recently a neurotoxic action of bee MCD peptide has been reported [7]. When injected in mice at a dose of $4 \mathrm{nmol} / \mathrm{kg}$ intracerebroventricularly, but not endovenously, the peptide causes convulsions and hyperactivity followed by death. In addition high affinity binding sites for bee MCD peptide have been reported in brain synaptic membranes [14]. In view of the structural similarity of bee and bumble bee MCD peptides. it would be not surprising if bumblebee MCD peptide also exerts a neurotoxic action and binds to brain membranes.

Although MCD peptides are present in the venom in very low concentration, their potent pharmacological action certainly justifies more investigation. The availability of synthetic MCD peptides will greatly facilitate the study of their mechanism of action and perhaps will permit the discovery of some yet unknown function of these peptides.

\section{ACKNOWLEDGEMENT}

We thank Dr. Ettore Appella. National Cancer Institute, for the automated microsequencing of bumblebee $\mathrm{MCD}$ peptide.

\section{REFERENCES}

1. Anton, A. H. and D. F. Sayre. A modified fluorometric procedure for tissue histamine and its distribution in various animals. $J$ Pharmacol Exp Ther 166: 285-292, 1969.

2. Argiolas, A. and J. J. Pisano. Facilitation of phospholipase $A_{2}$ activity by mastoparans, a new class of mast cell degranulating peptides from wasp venom. $J$ Biol Chem 258: 13697-13702. 1983.

3. Argiolas, A. and J. J. Pisano. Bombolitins, a new class of mast cell degranulating peptides from the venom of the bumblebee Megabombus pennsy/ianicus. J Biol Chem 260: 1437-1444. 1985.

4. Chang. J. Y.. D. Brauer and B. Wittman-Liebold. Microsequence analysis of peptides and proteins using 4-N.N-dimethylamino - azobenzene - 4' - isothiocyanate'phenylisothiocyanate double coupling method. FEBS Lett 93: 205-214. 1978.

5. Gray. W. R. Sequence analysis with dansyl chloride. In: Methods in En:ymology. Vol XXV. edited by C. H. W. Hirs and S. N. Timasheff. New York: Academic Press, 1972. pp. $333-344$.

6. Haberman. E. Bee and wasp venoms. Scicnce 117: 314-322. 1972

7. Haberman, E. Neurotoxicity of apamine and MCD peptide upon central administration. Nammy Schmicdeborgs Arch Phumucol 300: 188-191, 1977.

8. Haux. P. Die aminosaürense von MCD-peptid. einem spezifich mastzellendegranulierenden peptid aus bienengift. $Z$ Physiol Che'm 350: 536-546. 1969.
9. Hugues, M.. G. Romey, D. Duval, J. P. Vincent and M. Lazdunski. Apamine as a selective blocker of the calcium dependent potassium channel in neuroblastoma cells: voltage clamp and biochemical characterization of the toxin receptor. Proc Nall Acud Sci USA 79: 1308-1312. 1982.

10. Parker. D. S.. J. P. Raufman. T. L. Donohue. M. Bledsoe. H. Yoshida and J. J. Pisano. Amino acid sequences of helospectins. new members of the glucagon superfamily. found in Gila monster venom. J Biol Che'm 259: 11751-11755. 1984.

11. Spackman. D. H., W. H. Stein and S. Moore. Automated recording apparatus for use in the chromatography of amino acids. Anal Ch'm 30: 1190-1206. 1958.

12. Sullivan, T. J.. K. L. Parker. W. Stenson and F. W. Parker. Modulation of cyclic AMP in purified rat mast cells. 1. Responses to pharmacologic. metabolic and physical stimuli. $I$ Immunol 114: 1473-1479. 1975.

13. Tatemoto. K. and V. Mutt. Chemical determination of polypeptide hormones. Proc Natl Acad Sci USA 75: 4115-4119. 1978.

14. Taylor, J. W.. J. N. Bidard and M. Lazdunshi. The characterization of high affinity hinding sites in rat brain for the matst cell degranulating peptide from bee renom using the purified monoiodinated peptide. I Biol Che'm 259: 13957-13967. 1984.

15. Vernon. C. A.. J. M. Hanson and R. W. Brimblecombe. Peptides British Patent No. 1324823. 